\title{
THE APPLICATION OF ROLE PLAYING MODEL IN SOCIAL LEARNING ON GRADE IV STUDENTS' AT SUNGAI HITAM ELEMENTARY SCHOOL
}

\author{
Nanda Farira ${ }^{1}$, Andriana Sofiarini ${ }^{1}$, Tio Gusti Satria ${ }^{1}$ \\ ${ }^{{ }^{*}}$ STKIP PGRI Lubuklinggau \\ nandafarira@gmail.com
}

DOI: https://doi.org/10.21107/Widyagogik/v8i2. 8944

Received November 03, 2020; Revised November 05, 2020; Accepted january 21, 2021

\section{Abstract}

This study aims to determine completeness of student learning outcomes after the application of role playing model in Social learning on grade IV students at Sungai Hitam Elementary School. The method used in this research is Pre-Experimental Design. The population in this study is all grade IV of Sungai Hitam Elementary School. The research sample was taken using simple random sampling technique. Data collection techniques in the study using the test. Then the data were analyzed using the t-test. Based on the results of research and discussion it is known that the average value $(\bar{x})$ of pre-test is 40,12 and the average value $(\bar{x})$ of post-test is 77,71 . The collected data is then analyzed using the t-test obtained tcount $(3,34)>$ ttable $(1,75)$. It can be concluded that the learning outcomes of grade IV students' at Sungai Hitam Elementary School after the application of role playing model in Social learning completed significantly.

Keywords : Application, Role playing, Social learning. 
26 The Application of Role Playing Model in Social Learning on Grade IV Students' at Sungai Hitam Elementary School

Nanda Farira, Andriana Sofiarini, Tio Gusti Satria

\section{Introduction}

Education is one of the most important factors in the continuity of human life, with human education being able to advance their civilization. The world of education cannot be separated from learning activities both in formal and non-formal education. Learning activities are carried out by a person to gain knowledge or understanding that allows a change in behavior for the better. A learning process that involves interaction between teachers and students. During the learning process students can acquire, add and develop knowledge, insights, and skills.

The teacher plays a very important role in achieving success during the learning process. Therefore, teachers are required to be able to design a learning process that is active, innovative, creative, effective, and fun, so that it can increase students' understanding and learning experience and make learning more meaningful. The success of students in mastering learning materials can be seen from the learning outcomes obtained by students. The learning outcomes are indicated by a change in students such as changes in knowledge, attitudes and behavior, skills, proficiency, habits, and changes in other aspects.

One of the student learning outcomes that need to be seen is the social studies field. Social studies is a very broad science that studies the relationship between humans and the world around them, which includes social, economic, psychological, cultural, historical, and political relations. Sulaemi (2017: 73) argues that social science is a branch of science that studies, studies and analyzes social symptoms and problems in society by observing various aspects of life. Social studies learning aims to foster and increase knowledge, attitudes, and awareness as responsible citizens and to design learning management that can bring students closer to their real life. Social studies learning in elementary schools should not only be taught in terms of material and memorization, because social studies learning materials emphasize their daily lives.

Based on the results of observations made by the author at Sungai Hitam State Elementary School, seeing the social studies learning process that takes place in grade IV focuses more on teachers. Students only listen, pay attention, and are not active in the learning process so that students are less able to develop their knowledge, skills and potential in themselves. The teacher also does not vary learning activities or use learning media which causes students to feel bored, sleepy, lackluster, and noisy during the learning process. This has an impact on student learning outcomes to be less than optimal / low so that there are student learning outcomes that have not yet reached the KKM (Minimum Completeness Criteria). Based on the results of daily tests of fourth grade students in odd semester theme 1 sub-theme 1 for the 2020/2021 school year, the data shows that out of 17 students there are $6(35 \%)$ students whose scores have reached the KKM, which is 70, while $11(65 \%)$ students have not reach the KKM school with an average score of 68 .

A good learning process should focus more on students as subjects in learning and the teacher only acts as a facilitator. The 2013 curriculum requires students to be active in the learning process so that they can achieve maximum learning outcomes. In 
line with this Purbiyanti, Wasino \& Nuryatin (2017: 58) state that student activity during learning can result in a fresh and conducive classroom atmosphere, so that students are able to involve their abilities as much as possible so that it will shape their knowledge and skills that will have an impact on student learning outcomes.

Examining the problems that have been found during these observations, it is necessary to have a change and variation in carrying out learning activities. A teacher must play an active role in designing a learning process. The way that can be done to overcome this is by applying a learning model. One of the learning models that can be used is the role playing model. The role playing model is a method used in mastering learning material through developing students' imagination and appreciation by involving elements of fun. Therefore, using a role playing model can provide a real picture of the material being taught seeing that social studies learning is related to the social environment and real life of students. Not only that, by applying the role playing model students can also participate in being able to play an active role in conveying knowledge or information concerning the material and encouraging students to work together with their classmates and this learning can be more meaningful.

\section{Method}

This research is a quantitative research, the method used is pre-experimental design, namely the experiment which only uses one class without any control or comparison class with the research design that is one group pretest-posttest design.

This study has two variables, namely the independent variable and the dependent variable. The independent variable in this study is the role playing model and the dependent variable is the student's social studies learning outcomes. This research was conducted at the Sungai Hitam State Primary School for the 2020/2021 academic year. The population in this study were all fourth grade students at Sungai Hitam State Elementary School. The sampling technique was simple random sampling.

The data collection technique used was an essay-shaped test technique of 8 questions. The test was carried out before and after giving treatment to students. The data analysis technique in this study is to determine the average value, standard deviation, normality test, and hypothesis testing (t-test). The normality test is used to determine whether the data is normally distributed or not. After conducting the normality test, then conducting a hypothesis test using the t-test to measure whether the learning outcomes of grade IV students at Sungai Hitam State Elementary School after the application of the Role Playing Model in social studies learning are significantly complete.

\section{Result and Discussion}

\section{Pre-test Data Analysis}

The pre-test data analysis was conducted to determine the students' initial abilities before being given learning using the role playing model. 
28 The Application of Role Playing Model in Social Learning on Grade IV Students' at Sungai Hitam Elementary School

Nanda Farira, Andriana Sofiarini, Tio Gusti Satria

Table 1. Recapitulation of Pre-test Result Data

\begin{tabular}{cc}
\hline Category & Description \\
\hline Average value & 40,12 \\
Standard Deviation & 10,41 \\
Students Who Complete & 0 students (0\%) \\
Students Who Do Not & 17 students (100\%) \\
Complete & \\
\hline
\end{tabular}

Based on table 1 above, it can be seen that there are no students who have scored more than 70, all of whom score less than 70.The highest score in this pre-test is 59 and the lowest is 25 . So it can be concluded that the results of the students' pre-test before learning using the role playing model was still not in a good category because the students' average score was still less than 70 .

\section{Post-test data analysis}

Post-test data analysis was conducted to determine student learning outcomes after participating in the learning process using a role playing model.

Table 2. Recapitulation of Post-test Result Data

\begin{tabular}{cc}
\hline Category & Description \\
\hline Average value & 77,71 \\
Standard Deviation & 9,51 \\
Students Who Complete & 14 students (82\%) \\
Students Who Do Not & 3 students (18\%) \\
Complete & \\
\hline
\end{tabular}

Based on table 2 above, it can be seen that students who scored less than 70 were 3 students and those who scored more than 70 were 14 students. The highest score is 89 and the lowest is 61 . So it can be concluded that the post-test results of the students after learning using the role playing model are in the good category because the students' average score is more than or equal to.

\section{Data Normality Test}

The normality test is carried out to see whether the data is normally distributed or not. The formula used to calculate the normality test is the Chi Square formula ( $\chi 2)$. Based on the statistical calculation provisions regarding the data normality test with a significant level $\alpha=0,05$, if $\chi 2$ count $<\chi 2$ table, then the data is normally distributed. The results of the analysis of normality test data can be seen in table 3 .

Table 3. Normality Test Results

\begin{tabular}{ccccc}
\hline Test & $\boldsymbol{\chi}_{\text {count }}^{2}$ & $\mathbf{d k}$ & $\boldsymbol{\chi}_{\text {table }}^{2}$ & Conclusion \\
\hline Post-test & 7,60 & 4 & 9,49 & Normal \\
\hline
\end{tabular}


Based on table 3 shows that the value $\chi 2$ count $<\chi 2$ table then the data is normally distributed. So, it can be concluded that the post-test result data is normally distributed.

\section{T-test}

The t-test is used to calculate the hypothesis test and draw conclusions from the post-test result data, the t-test is used because the data is normally distributed and the population standard deviation is unknown. The results of the t-test calculation can be seen in table 4.

Table 4. $t$ - test result

\begin{tabular}{ccccc}
\hline Test & $\mathbf{t}_{\text {count }}$ & $\mathbf{d k}$ & $\mathbf{t}_{\text {table }}$ & Conclusion \\
\hline Post-test & 3,34 & 16 & 1,75 & $\begin{array}{c}\text { Ha accepted, } \\
\text { Ho was } \\
\text { rejected }\end{array}$ \\
\hline
\end{tabular}

Based on table 4 above is obtained tcount $=3,34$ dan ttable $=1,75$ to a significant degree $\alpha=0,05$. This shows that tcount $>$ ttable, that is $3,34>1,75$ so it can be stated that $\mathrm{Ha}$ is accepted and $\mathrm{Ho}$ is rejected. Thus the hypothesis proposed in this study can be accepted as true, it can be concluded that the learning outcomes of grade IV students at Sungai Hitam State Elementary School after the application of the role playing model in social studies learning are significantly complete.

\section{Conclusion}

Based on the results of research and discussion of the application of the role playing model in social studies learning for fourth grade students at Sungai Hitam State Elementary School, it was obtained that the pre-test average score $(\bar{x})$ was 40.12 and the post-test average score $(\bar{x})$ was 77.71 , this means there is an increase in the average score of students. Then the data were analyzed using t-test and obtained tcount $(3,34)>$ ttable $(1,75)$ so that it can be stated that $\mathrm{Ha}$ is accepted and $\mathrm{Ho}$ is rejected. Thus it can be concluded that the learning outcomes of fourth grade students at Sungai Hitam State Elementary School after the application of the role playing model in social studies learning are significantly complete. 
30 The Application of Role Playing Model in Social Learning on Grade IV Students' at Sungai Hitam Elementary School

Nanda Farira, Andriana Sofiarini, Tio Gusti Satria

\section{References}

Ahmadi, K.I \& Amri, S. (2011). Metode Pembelajaran IPS Terpadu: “Analisis Kritis tentang Metode, Strategi, Evaluasi, dan Media Pembelajaran Bidang Studi Sejarah, Geografi, Ekonomi, Sosiologi, Antropologi dan Isu Pembelajaran IPS Terpadu". Jakarta: Prestasi Pustaka Karya.

Arikunto, Suharsimi. (2013). Prosedur Penelitian Suatu Pendekatan Praktik. Jakarta: Rineka Cipta.

Ariyana, Y., Pudjiastuti, A., Bestary, R., Zamroni. (2018). Buku Pegangan Pembelajaran Berorientasi Pada Keterampilan Berpikir Tingkat Tinggi.

Darmadi. (2017). Pengembangan Model Metode Pembelajaran dalam Dinamika Belajar Siswa. Yoyakarta: Deepublish.

Fathurrohman, Muhammad. (2016). Model-Model Pembelajaran Inovatif: Alternatif Desain Pembelajaran yang Menyenangkan. Jogjakarta: Ar-Ruzz Media.

Hamdayana, Jumanta. (2017). Model dan Metode Pembelajaran Kreatif dan Berkarakter. Bogor: Penerbit Ghalia Indonesia.

Jakni. (2016). Metodologi Penelitian Eksperimen Bidang Pendidikan. Bandung: Alfabeta.

Jihad, A \& Haris, A. (2012). Evaluasi Pembelajaran. Yogyakarta: Multi Pressindo.

Kurniasih, I. \& Sani, B. (2016). Ragam Pengembangan Model Pembelajaran: untuk Peningkatan Profesionalitas Guru. Jakarta: Kata Pena.

Mariyaningsih, N. \& Hidayati, M. (2018). Bukan Kelas Biasa: Teori dan Praktik Berbagai Model dan Metode Pembelajaran Menerapkan Inovasi Pembelajaran di KelasKelas Inspirtif. Surakarta: Kekata Publisher.

Ngalimun. (2014). Strategi dan Model Pembelajaran. Yogyakarta: Aswaja Pressindo.

Nurdyansyah \& Fahyuni, F.E. (2016). Inovasi Model Pembelajaran: Sesuai Kurikulum 2013. Sidoarjo: Nizamia Learning Center.

Purbiyanti, D.E., Wasino \& Nuryatin, A., (2017). Keefektivan Penerapan Model Role Playing dan Storytelling terhadap Aktivitas dan Hasil Belajar IPS. JPE, 6 (1), 57-64, E-ISSN: 2502-4515.

Rusman. (2011). Model-Model Pembelajaran: Mengembangkan Profesionalisme Guru. Jakarta: PT Rajagrafindo Persada.

. (2017). Belajar dan Pembelajaran Berorientasi Standar Proses Pendidikan. Jakarta: Kencana.

Sari, E.Y., Suastiaji, B.I. \& Permata, L. (2016). Pengaruh Penggunaan Model Role Playing dengan Media Video terhadap Hasil Belajar IPS (Studi Eksperimen pada Siswa Kelas V SD Islam Al-Gontory Tulungagung). PENA SD (Jurnal Penddikan dan Pembelajaran Anak Sekolah Dasar), 2 (1), 23-37, E-ISSN: 2477-8486.

Slameto. (2010). Belajar dan Faktor-Faktor yang Mempengaruhinya. Jakarta: PT Rineka Cipta.

Suhada, Idad. (2017). Konsep Dasar IPS. Bandung: PT Remaja Rosdakarya. 
Sulaemi, Eem. (2017). Penerapan Model Pembelajaran Kooperatif Bermain Peran (Role Playing) pada Mata Pelajaran IImu Pengetahuan Sosial untuk Meningkatkan Hasil Belajar Siswa Kelas III di SD Negeri Setragalih Kecamatan Cibogo Kabupaten Subang. BIORMATIKA Jurnal IImiah FKIP Universitas Subang, 4(1) 2461-3961, ISSN: 2461-3961.

Sugiyono. (2017). Metode Penelitian Kuantitatif, Kualitatif, dan R\&D. Bandung: Alfabeta. . (2017). Statistika untuk Penelitian. Bandung: Alfabeta.

Suprihatiningrum, Jamil. (2016). Strategi Pembelajaran: Teori dan Aplikasi. Jogjakarta: Ar-Ruzz Media.

Susanto, A. (2013). Teori Belajar dan Pembelajaran di Sekolah Dasar. Jakarta: Kencana Prenada Media Group.

- (2016). Pengembangan Pembelajaran IPS Di Sekolah Dasar. Jakarta: Prenadamedia Group.

Syarifudin, dkk. (2010). Strategi Belajar Mengajar. Jakarta: Diadit Media.

Tarigan, Arleni. (2016). Penerapan Model Pembelajaran Role Playing Untuk Meningkatkan Hasil Belajar IPS Siswa Kelas III SD Negeri 013 Lubuk Kembang Sari Kecamatan Ukui. Jurnal Primary Program Studi Pendidikan Guru Sekolah Dasar Fakultas Keguruan dan Ilmu Pendidikan Universitas Riau, 5 (3), ISSN: 2303-1514.

Trianto. (2010). Model Pembelajaran Terpadu: Konsep, Strategi, dan Implementasinya dalam Kurikulum Tingkat Satuan Pendidikan (KTSP). Jakarta: Bumi Aksara.

Wahyuni, I., Slameto \& Setyanigtyas, W.E. (2018). Penerapan Model PBL Berbantuan Role Playing untuk Meningkatkan Motivasi dan Hasil Belajar IPS. Jurnal IImiah Sekolah Dasar, 2 (4), 356-363, E-ISSN: 2549-6174.

Widya, R. (2019). Penerapan Model Pembelajaran Role Playing untuk Meningkatkan Hasil Belajar IPS Siswa Kelas IV SDN 183 Pekanbaru. Prossiding Seminar Nasional Pendidikan Guru Sekolah Dasar, hal. 80-93. ISBN: 978-623-91681-0-0, DOI: http://dx.doi.org/10.33578/psn.v1i1.7783

(C) 2021 by the authors. Submitted for possible open access publication under the terms and conditions of the Creative Commons Attribution ShareAlike (CC BY SA) license (https://creativecommons.org/licenses/by-sa/4.0/). 